\title{
Increasing urban water self-sufficiency: New era, new challenges
}

Rygaard, Martin; Binning, Philip John; Albrechtsen, Hans-Jørgen

Published in:

Journal of Environmental Management

Link to article, DOI:

10.1016/j.jenvman.2010.09.009

Publication date:

2011

Document Version

Peer reviewed version

Link back to DTU Orbit

Citation (APA):

Rygaard, M., Binning, P. J., \& Albrechtsen, H-J. (2011). Increasing urban water self-sufficiency: New era, new challenges. Journal of Environmental Management, 92(1), 185-194.

https://doi.org/10.1016/j.jenvman.2010.09.009

\section{General rights}

Copyright and moral rights for the publications made accessible in the public portal are retained by the authors and/or other copyright owners and it is a condition of accessing publications that users recognise and abide by the legal requirements associated with these rights.

- Users may download and print one copy of any publication from the public portal for the purpose of private study or research.

- You may not further distribute the material or use it for any profit-making activity or commercial gain

- You may freely distribute the URL identifying the publication in the public portal

If you believe that this document breaches copyright please contact us providing details, and we will remove access to the work immediately and investigate your claim 
Postprint of published article in J. Environmental Management 92 (2011) 185-194

doi:10.1016/j.jenvman.2010.09.009

Title: Increasing urban water self-sufficiency: New era, new challenges

Authors:

Martin Rygaard*, Philip J. Binning and Hans-Jørgen Albrechtsen

Author address: Department of Environmental Engineering, Technical University of Denmark, Miljøvej, Bygning 113, DK-2800 Kgs. Lyngby, Denmark, phone: +45 45251570

*Corresponding author e-mail address: $\underline{\text { mryg @env.dtu.dk }}$ 


\begin{abstract}
Water supplies are traditionally based on limited fresh water resources located in the areas surrounding the cities. However, a range of concepts and techniques to exploit alternative water resources have now won ground as water demands are closing in on the fresh water available to cities. Based on 113 cases and 15 in-depth case studies, the drivers are identified and solutions behind increased water self-sufficiency in urban areas are analyzed. The main drivers for increased self-sufficiency were identified to be direct and indirect lack of water, constrained infrastructure, high quality water demands and commercial and institutional pressures. The cases demonstrate increases in selfsufficiency ratios to as much as $80 \%$ with contributions from recycled water, seawater desalination and rainwater collection. The introduction of alternative water resources raises several challenges: Energy requirements vary by more than a factor of ten amongst the alternative techniques, wastewater reclamation allows trace contaminants to reach the drinking water, and changes to the drinking water system can meet tough resistance from the public. Public water supply managers aim to reach a high level of reliability and stability using cost and environmentally effective techniques. We conclude that despite the challenges, self-sufficiency concepts in combination with conventional water resources are already helping to reach this goal.
\end{abstract}




\section{Introduction}

Water supply systems have undergone several revolutions in the era of human civilization. Advanced irrigation systems existed in the ancient Middle East and India thousands of years before the Romans refined the art of conveying water with impressive aqueducts and sewage systems (Mays et al. 2007). Later, in 19th century Europe, the hygienic movement triggered massive investment in water infrastructure. Systems were constructed to deliver clean drinking water and remove sewage from urban areas in separate systems (Hallström 2003). Today long water transport and separate water supply and sewage systems are the most common water systems. They have enabled people to grow crops and live where freshwater is not readily available and have been a huge success as they have practically eliminated waterborne diseases in most of the developed world.

We are now entering an era of a new water revolution, again driven by population growth and urbanization, which is challenging the limits of our conventional water resources. In recent decades, as populations have grown, cities in the developed world have expanded abstraction rates, imported water from further away, and struggled to reduce consumption rates to cope with increasing water demand.

These approaches are no longer adequate now that more than half the world's population lives in urban areas (Martine 2007). Water suppliers are now turning to new technologies and strategies that increase self-sufficiency by enabling the use of water sourced from within the cities. Localization of water cycles through neighborhood reclamation and distribution of water has several benefits including minimization of piping systems and reduced water extraction and discharge of sewage to recipients (van Roon 2007). However, localization of water treatment is only one example of increased 
water self-sufficiency; water is increasingly sourced close to the city rather than being transported from distant resources. On the city scale, several options for increasing selfsufficiency exist, including unconventional water resources like centralized wastewater reclamation, desalination and local and central rainwater collection.

In the following review we will show how self-sufficiency techniques and concepts are beginning to contribute significantly to urban water supplies. We analyze and discuss the techniques and concepts used to increase water self-sufficiency on the city scale. The aim is to investigate the implications of a worldwide increase in urban water selfsufficiency, to identify the drivers behind the change, and to investigate the main consequences and scientific challenges that follow.

\section{Method and data collection}

Examples of current projects that attempt to increase the self-sufficiency of an urban area were found in the scientific literature as well as the internet. Numerous examples exist and a screening list of 113 cases was compiled including examples from around the world. The collection was intentionally restricted to be representative of possible solutions, and so does not contain every single project encountered during the search. For example, many desalination projects were omitted, since they were repetitive instances of reverse osmosis membrane set-ups. As the focus has been on identifying current trends and recent projects, several examples have not yet been described in the literature and information had to be obtained from internet sources and local stakeholders. 
Table 1. Cases analyzed in depth as background for this article. In-depth descriptions of

the 15 cases are presented elsewhere (Rygaard et al. 2009).

\begin{tabular}{|c|c|c|c|}
\hline \multicolumn{2}{|c|}{ Location } & \multirow{2}{*}{$\begin{array}{l}\text { Technology \& } \\
\text { concepts in use }\end{array}$} & \multirow{2}{*}{$\begin{array}{l}\text { Description } \\
\text { Mandatory rainwater collection for toilet and clothes washing from the roofs with local infiltration. } \\
\text { Good experiences with obligatory rainwater collection, reducing drinking water consumption by } 25 \% \\
\text { in a new residential area. }\end{array}$} \\
\hline 1 & $\begin{array}{l}\text { Stenlose Syd, Egedal } \\
\text { municipality } \\
\text { Denmark }\end{array}$ & & \\
\hline 2 & $\begin{array}{l}\text { Hammarbysjøstad, } \\
\text { Stockholm } \\
\text { Sweden }\end{array}$ & Water planning & $\begin{array}{l}\text { Green district, water-saving installations and local management of all wastewater } \\
\text { Despite the focus on water savings, the consumption is still higher }(1501 / \mathrm{cap} / \mathrm{d}) \text { than most efficient } \\
\text { cities, e.g. Berlin }(110 \mathrm{l} / \mathrm{cap} / \mathrm{d}) \text {. }\end{array}$ \\
\hline 3 & $\begin{array}{l}\text { Millennium Dome, } \\
\text { London } \\
\text { Great Britain }\end{array}$ & $\begin{array}{l}\text { Recycled water } \\
\text { Recycling } \\
\text { Rainwater }\end{array}$ & $\begin{array}{l}\text { Rainwater, grey wastewater and polluted groundwater were used in toilets and urinals in the arena. } \\
\text { Expensive full-scale demonstration project, where alternative water resources covered } 55 \% \text { of the } \\
\text { building's water consumption. }\end{array}$ \\
\hline 4 & $\begin{array}{l}\text { Torreele, Wulpen } \\
\text { Belgium }\end{array}$ & Recycling & $\begin{array}{l}\text { Recycling of wastewater via the groundwater zone. Used for drinking water supply. } \\
\text { European example of recycling of wastewater for drinking water via groundwater with membrane } \\
\text { filtration. }\end{array}$ \\
\hline 5 & $\begin{array}{l}\text { Costa Brava } \\
\text { Spain }\end{array}$ & Recycling & $\begin{array}{l}\text { Recycling of wastewater via simple treatment techniques in preparation for artificial groundwater } \\
\text { development. } \\
\text { European example of cheap recycling of wastewater for groundwater without membrane filtration. }\end{array}$ \\
\hline 6 & $\begin{array}{l}\text { Berlin } \\
\text { Germany }\end{array}$ & Recycling & $\begin{array}{l}\text { Partly closed water circulation around the town. Unplanned wastewater recycling for drinking water } \\
\text { supplies via bank infiltration and artificial groundwater development. } \\
\text { Experiences around transport of problematic substances in cases of household wastewater recycling } \\
\text { for drinking water supply. }\end{array}$ \\
\hline 7 & $\begin{array}{l}\text { Potsdamer Platz, } \\
\text { Berlin } \\
\text { Germany }\end{array}$ & Rainwater & $\begin{array}{l}\text { Collection of rainwater in town centre, cleaned via green roofs and beds, and used in artificial } \\
\text { outdoor water settings and toilets. } \\
\text { Integrated water management limiting wastewater and water consumption, and creating a better urban } \\
\text { environment. }\end{array}$ \\
\hline 8 & $\begin{array}{l}\text { Orange County, } \\
\text { California } \\
\text { USA }\end{array}$ & Recycling & $\begin{array}{l}\text { Artificial groundwater infiltration based on wastewater used as a salt water barrier. Ground water is a } \\
\text { part of the drinking water supply. } \\
\text { One of the pioneer places within reuse of wastewater to which many people refer. }\end{array}$ \\
\hline 9 & $\begin{array}{l}\text { Rio Rancho, New } \\
\text { Mexico } \\
\text { USA }\end{array}$ & Recycling & $\begin{array}{l}\text { Membrane-bioreactor can be used for recycling of wastewater for irrigation and eventually to be } \\
\text { injection in the drinking water aquifers. } \\
\text { The MBR system is different from the other recycling systems, where conventional wastewater } \\
\text { purification techniques are used. }\end{array}$ \\
\hline 10 & $\begin{array}{l}\text { Windhoek } \\
\text { Namibia }\end{array}$ & Recycling & $\begin{array}{l}\text { Direct recycling of wastewater for drinking water use has been practiced since } 1968 \text {. } \\
\text { A unique example of direct utilization of household wastewater for drinking water supply. }\end{array}$ \\
\hline 11 & Singapore & $\begin{array}{l}\text { Desalination } \\
\text { Water planning } \\
\text { Recycling } \\
\text { Rainwater }\end{array}$ & $\begin{array}{l}\text { Comprehensive, long term plan to make Singapore self-sufficient with drinking water. Desalination } \\
\text { of sea water, recycling of wastewater for industry and drinking water consumption and rainwater are } \\
\text { a part of the plan. } \\
\text { A unique example of a strong desire to be independent of imported water in a large city. An } \\
\text { important PR work has made the example well-known. }\end{array}$ \\
\hline 12 & $\begin{array}{l}\text { Seoul } \\
\text { Korea }\end{array}$ & $\begin{array}{l}\text { Water planning } \\
\text { Rainwater }\end{array}$ & $\begin{array}{l}\text { Obligatory collection of rainwater as a secondary water supply, where the rainwater collecting is } \\
\text { centrally coordinated with a view to levelling the wastewater discharge after heavy precipitations. } \\
\text { The obligatory collection of rainwater is limited to public buildings, but interesting teamwork } \\
\text { between wastewater management and water savings. }\end{array}$ \\
\hline 13 & $\begin{array}{l}\text { Tokyo } \\
\text { Japan }\end{array}$ & $\begin{array}{l}\text { Recycling } \\
\text { rainwater }\end{array}$ & $\begin{array}{l}\text { Comprehensive use of recycled wastewater as a secondary water supply. Recycling is obligatory in } \\
\text { all new buildings over } 30,000 \mathrm{~m}^{3} \text {. } \\
\text { The example shows that wastewater can be treated and recycled locally in one single home or on a } \\
\text { block of flats. }\end{array}$ \\
\hline 14 & $\begin{array}{l}\text { Perth } \\
\text { Australia }\end{array}$ & Desalination & $\begin{array}{l}\text { A large scale membrane desalination of seawater for drinking water consumption, based on purchase } \\
\text { of electricity from a wind farm. } \\
\text { Interesting with } \mathrm{CO}_{2} \text { neutral water supply, based on energy-demanding desalination. }\end{array}$ \\
\hline 15 & $\begin{array}{l}\text { Gold Coast, } \\
\text { Australia }\end{array}$ & $\begin{array}{l}\text { Desalination } \\
\text { Water planning } \\
\text { Recycling } \\
\text { Rainwater }\end{array}$ & $\begin{array}{l}\text { Comprehensive general plan for water management, including desalination of seawater, recycling for } \\
\text { non-drinking water use, rainwater collection and water economising. In the town district Pimpama- } \\
\text { Coomera, they aim for a reduction of up to } 84 \% \text { of the drinking water consumption. } \\
\text { Integrated water management, gathering many experiences of practical realisation of water planning, } \\
\text { planning and involvement of citizens. }\end{array}$ \\
\hline
\end{tabular}


Based on the review of the 113 cases, 15 cases ( 
Table 1) were found to represent most techniques and concepts and were subsequently analyzed in-depth. The analysis had 3 main focuses: 1) to identify the driving forces (drivers) and policies leading to the change to a more self-sufficient water supply, 2) to describe and analyze techniques and concepts put in place to realize aims of increased the self-sufficiency, and finally 3) to analyze challenges met or occurring due to the change, including public perception, costs, and environmental impacts. The screening list and detailed description of the cases is reported elsewhere (Rygaard et al. 2009).

\subsection{Self-sufficiency in water supply}

A concept of urban water self-sufficiency has been proposed as a measure of urban dependency on water imports (Han \& Kim 2007). To evaluate self-sufficiency we define the self-sufficiency ratio as $\mathrm{Q}_{\mathrm{lr}} / \mathrm{Q}_{\mathrm{td}}$, where $\mathrm{Q}_{\mathrm{lr}}$ is the amount of water sourced from within a given area, i.e. recycled wastewater, harvested rainwater or desalinated water from local shores and $\mathrm{Q}_{\mathrm{td}}$ is the total water demand in the same area, e.g. a single building or a larger urban area. The definition employed shows that the self-sufficiency ratio depends on the definition of the area or system boundaries. Here the system boundaries for each case are defined to be its geographic boundaries.

\section{Solutions}

\subsection{Spatial distribution}

The reviewed cases reveal that a vast variety of solutions to increased water selfsufficiency in urban areas are widespread around the world (Table 2). Examples are found on every continent, however our collection is biased towards larger European and other westernized countries, probably due to availability of information in English on the subject, rather than any geographic trends. A bias towards the industrialized parts of 
the world is intentional since the main focus is on solutions in industrialized urban areas.

Table 2 Geographical and topical distribution of the cases referred to in this article.

\begin{tabular}{lrr}
\hline Geographical distribution & Number of cases & Percentage \\
\hline Europe & 46 & $41 \%$ \\
North America & 18 & $16 \%$ \\
Sub-sahara Africa & 4 & $4 \%$ \\
Asia & 15 & $13 \%$ \\
Australia & 17 & $15 \%$ \\
South America & 2 & $2 \%$ \\
Middle East & 11 & $10 \%$ \\
\hline Total number of cases screened & 113 & $100 \%$ \\
\hline
\end{tabular}

\subsection{Drivers}

Five main drivers appeared behind the increasing self-sufficiency ( 
Table 3): 1) Direct and 2) indirect lack of water, 3) constrained infrastructure, 4) high quality water demands and 5) the sectoral system. 
Table 3. Drivers for increased water self-sufficiency

Driving forces behind water reuse, desalination and rainwater collection Case examples (Table

1)

1. Direct lack of water caused by

a. Drought (reduced resource availability)

$3,4,5,8,9,10,12,13$

14,15

b. Population growth (increased demand)

5,11

2. Indirect lack of water caused by policy changes:

a. Increased emphasis on environmental flows (nature restoration)

b. Wish to be independent of water imports (from surrounding areas/other countries)

3. Constrained infrastructure limiting capacity for water supply and drainage

4. Demand for high quality water from industry

5. The sectoral system governed by commercial, organizational and institutional interactions

\subsubsection{Direct lack of water}

We define direct lack of water as when the supply can not meet the anthropogenic demand needed for households and irrigation. The deficit may occur as a result of decreased supply (drought) or as a result of increased demand (population growth). Drought and population growth are common arguments for implementing alternative water strategies, for example in the Mediterranean countries and the Southwest of North America. From 2000 to 2025 the population in the Mediterranean countries is expected to increase by 97 million to 524 million people, with the highest increase in the cities (Fatta et al. 2006), and this population increase present major challenges in areas where the available water resources are already fully exploited. As we will see, desalination is playing a large role in this region (section 3.3.6). For example, the water demand/availability ratio is reported to be $89 \%$ for Cyprus and $103 \%$ for Jordan respectively (Fatta et al. 2006). These percentages may cautiously be compared with the EU EPA Water Exploitation Index, which state that utilization $>40 \%$ may lead to severe 
water stress (Lallana \& Marcuello 2004).

In North America, the Rio Grande runs through a desert region (Colorado, New Mexico, Texas, and the Mexican state of Chihuahua), an area recently hit by extreme drought. More than three million people are dependent on the Rio Grande, among them the inhabitants of the Albuquerque Metropolitan Area (Rio Rancho, El Paso, and Ciudad Juárez), where a rapidly increasing population has lead to a complicated task of water allocation for the population, agriculture and wildlife (Ward et al. 2006). Such examples are instances of direct water deficit where there is an insufficient amount of water available for anthropogenic demand. In Rio Rancho ( 
Table 1, case 9) the situation has lead to reclamation of wastewater.

\subsubsection{Indirect lack of water}

Indirect lack of water can be defined as the case where anthropogenic demand could be met, but sufficient water is not available. The deficit occurs because water is needed to sustain ecosystems or because it is based on politically unwanted water imports. For example, water resource pressures have increased in Europe due to the consideration of ecosystems in the European Water Framework Directive. Member states of the European Union are now obliged to a framework that "...prevents further deterioration and protects and enhances the status of aquatic ecosystems and, with regard to their water needs, terrestrial ecosystems and wetlands directly depending on the aquatic ecosystems" (Article 1a). Member states must implement management plans that consider both water quality and quantity (The European Parliament and the Council of the European Union 2000). Restoration of natural ecosystems is now a highly ranked political issue and has become an important driver for increasing self-sufficiency. Reclamation of water in Costa Brava in Spain is one example (cf. section 3.3.2).

Singapore is another example of indirect water deficit. The country currently depends on water imports from neighboring Malaysia. However, the two countries cannot agree on the price-setting mechanisms for water imports in the future. As a result, Singapore is now determined to become less dependent on water imports from Malaysia (Tortajada 2006). The plan is increased use of desalinated water, wastewater reclamation and rainwater collection. An indirect water deficit can therefore originate in a wish to allocate water to the environment or through a wish to avoid political conflict.

\subsubsection{Constrained infrastructure}


The driver constrained infrastructure is defined as the situation where bottlenecks in the water supply occur due to limited capacity of the infrastructure. Pipe systems designed decades earlier may be expensive to upgrade and restrain amounts of water to supply or remove from an area after use. As already mentioned by van Roon ( 2007), constrained infrastructure may drive a self-sufficiency trend. For example, constrained infrastructure has been identified as a direct driver for the development of local wastewater treatment in some of Japan's megacities where it prevents expensive investments in up-scaling of the central sewer systems (Ogoshi et al. 2001).

\subsubsection{Demand for high quality water}

A fourth driver is defined as a demand for high quality water, i.e. water that is even purer than required for potable supply. For example, the growing electronics industry in Singapore is driving an expansion of water reclamation, since ultra pure water is often required. For example, the wafer industry has high demands for demineralized water (cf. section 3.3.2).

\subsubsection{The sectoral system}

Innovation and development occur within a sectoral or innovation system as a result of the knowledge base and interactions that exist among the system agents, i.e. firms, universities, authorities etc. (Malerba 2002). Although not being a direct driver for specific self-sufficiency trends, the sectoral system defines the framework for the development. Commercial and institutional pressures are locally influenced by the technological paradigms employed by the commercial and non-commercial bodies and institutions in the area (Mulder 2006). Paradigms are reflected in regulations, standards, labor markets etc. It is possible, when firms, authorities, universities and related organizations build up knowledge and experience within e.g. desalination, that they 
develop biases, intentionally or otherwise, toward their own commercial or institutional interests. It is difficult to measure how much such paradigms drive the development, but examples suggest that they have a big impact.

An example of a framework promoting advanced water treatment technologies is found in Singapore where there is a widespread consensus that changes are needed that favor both public systems and industry. There is a common aim amongst industry, educational institutions and the government to develop state-of-the-art solutions in order to make the country as a world leader in water technology. This aim has resulted in several high profile treatment plants, like the Sing Spring Desalination plant, Changi water reclamation plant (Landers 2008), and the combined networking and educational facility WaterHub. Sing Spring Desalination Plant is one of the World's largest reverse osmosis desalination plants based on reverse osmosis technology and is operated by a local membrane manufacturer (Foo et al. 2007). The WaterHub operates as a center for exchanging research on water management between academia and industry domestically as well as internationally (WaterHub 2008).

\subsection{Techniques and concepts for self-sufficiency}

The screening list includes the major solutions (wastewater reclamation, desalination and rainwater collection) to increase water self-sufficiency, and all solution types are represented in the cases chosen for detailed analysis ( 


\section{Table 1).}

Increased self-sufficiency is linked to rapid developments of three main approaches to water supply, namely wastewater reclamation, desalination and rainwater collection. A majority of urban areas consume far more water than is available within their own city limits and often depend entirely on water imported from neighboring areas. As an example, the suburb Stenløse Syd consists of 750 dwellings with an annual water demand of $90000 \mathrm{~m}^{3} .23000 \mathrm{~m}^{3}$ is provided by rooftop collection of rainwater while the remainder will be imported from the public water supply. As defined above, the selfsufficiency ratio is found as $23000 \mathrm{~m}^{3} / 90000 \mathrm{~m}^{3}$ or $26 \%$ (Table 4). 


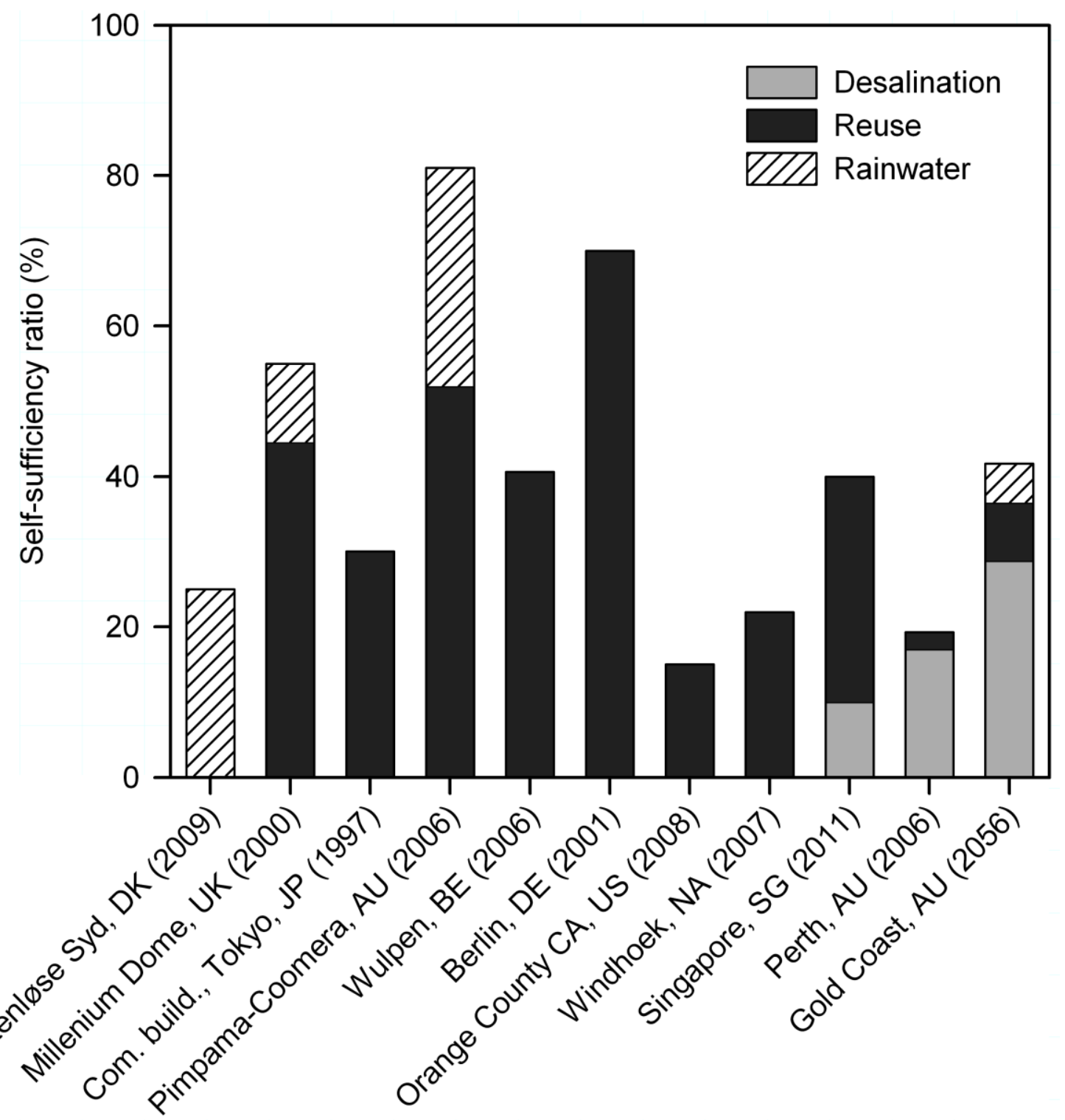

Figure 1. Reported water self-sufficiencies in selected urban areas and buildings (reported or planned year) (Table 4).

Current water supply systems commonly use no local resources, and the self-sufficiency ratio is $0 \%$. However, some cities have reduced their dependency on imported water by more than $15 \%$ e.g. by rainwater collection ( Figure 1). Thus self-sufficiency ratios can be quite high, e.g. isolated islands with no freshwater import have a self sufficiency ratio of $100 \%$. Water reclamation, desalination and rainwater collection can 
contribute significantly to urban water self-sufficiency ( Figure 1). Thus the ratio varies in the selected cases, from $15 \%$ in Orange County, California, to more than $80 \%$ in Pimpama-Coomera, Australia. It is also noted that the technologies work on different scales ranging from, for example, Stenløse Syd (1500 inhabitants), to Wulpen $(60,000)$ and Perth (1.5 mill.) (Table 4).

Table 4. Water supply alternatives and their volumes for selected cases.

\begin{tabular}{|c|c|c|c|c|c|}
\hline \multirow[t]{2}{*}{$\begin{array}{l}\text { Location (reported or planned } \\
\text { year) }\end{array}$} & Wate & r source $(1000 \mathrm{n}$ & & \multirow[t]{2}{*}{$\begin{array}{r}\text { Total } \\
\text { consumption } \\
(1000 \mathrm{~m} 3 / \mathrm{y}) \\
\end{array}$} & \multirow[t]{2}{*}{ Area } \\
\hline & $\begin{array}{r}\text { Local } \\
\text { desalination }\end{array}$ & $\begin{array}{r}\text { Wastewater } \\
\text { reuse }\end{array}$ & $\begin{array}{l}\text { Collected } \\
\text { rainwater }\end{array}$ & & \\
\hline Stenløse Syd, DK (2009) ${ }^{1}$ & & & 23 & 90 & 750 Dwellings \\
\hline Millenium Dome, UK $(2000)^{2}$ & & 58 & 14 & 131 & Public building \\
\hline Com. build., Tokyo, JP (1997) & & $(30 \%)$ & & N/A & Office building \\
\hline Pimpama-Coomera, AU (2006) & & 168 & 94 & 324 & Tenement \\
\hline Wulpen, BE (2006) ${ }^{5}$ & & 2199 & & 5412 & Supply zone \\
\hline Berlin, DE $(2001)^{6}$ & & 139300 & & 199000 & Supply zone \\
\hline Orange County CA, US (2008) ${ }^{7}$ & & 88811 & & 594538 & Supply zone \\
\hline Windhoek, NA $(2007)^{8}$ & & 4852 & & 22118 & Supply zone \\
\hline Singapore SG $(2011)^{9}$ & 41500 & 131400 & & 438000 & Supply zone \\
\hline Perth, AU $(2006)^{10}$ & 45000 & 6096 & & 264706 & Supply zone \\
\hline Gold Coast, AU (2030) ${ }^{11}$ & 40515 & 10950 & 7300 & 140890 & Supply zone \\
\hline
\end{tabular}

\subsubsection{Wastewater reclamation}

Wastewater reclamation as a source for irrigation and groundwater recharge for both urban and non-urban uses is increasing in all parts of the world. Thousands of water reclamation projects are running throughout USA, Japan and Australia and their number is increasing rapidly (European Commission 2006). The EU has relatively few wastewater reclamation projects, but has a great potential for development of water reclamation facilities (Hochstrat et al. 2006). Reclamation may even be cost efficient, 
and it is estimated to be cost effective to reclaim $6 \%$ of total urban wastewater produced in China, a percentage that will increase rapidly with increasing costs of water supply (Chu et al. 2004).

For urban wastewater reclamation applications we distinguish between non-potable reclamation $(A)$, indirect potable reclamation $(B)$ and direct potable reclamation $(C)($ Figure 2).

A: Non-potable reclamation of wastewater
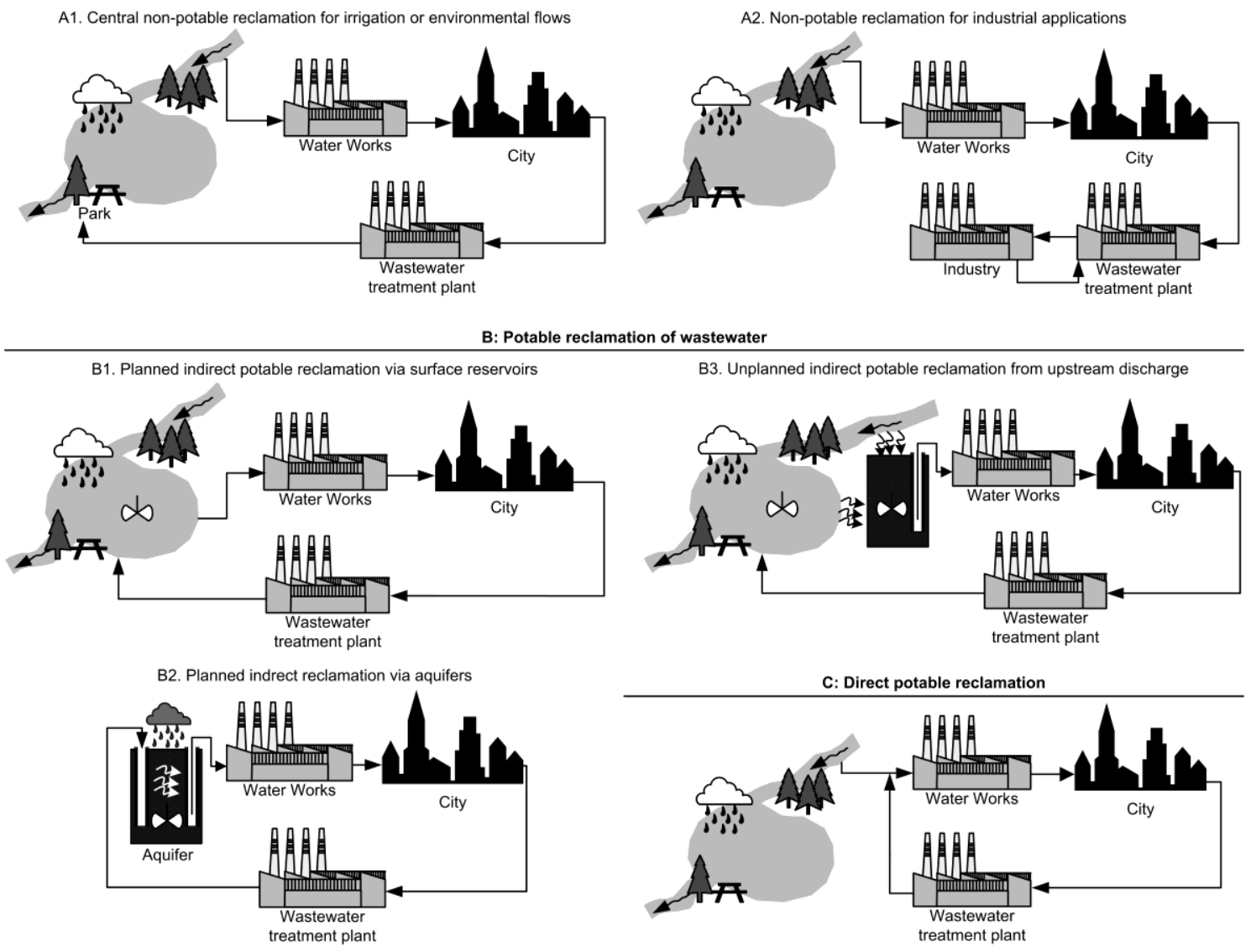

Figure 2. Examples of central wastewater reclamation.

\subsubsection{Non-potable reclamation}

Non-potable urban reclamation covers use of water for irrigation, nature restoration (environmental flows), household toilet flushing, and industrial process water. In Japan's megacities there are now thousands of on-site reclamation plants connected 
to public and commercial buildings. These plants typically replace $30 \%$ of the water used in such buildings, mainly for toilet flushing (Yamagata et al. 2003).

On a larger scale, water is reclaimed for irrigation and to reestablish environmental flows where water is withdrawn for water supply. For example, in Costa Brava, Spain, wastewater reclamation includes a plant based on constructed wetlands (>600 000 $\mathrm{m}^{3} / \mathrm{yr}$ ) and an advanced treatment plant including coagulation, flocculation, clarification, filtration and disinfection (>3 $000000 \mathrm{~m}^{3} / \mathrm{y}$ ) (Sala \& Romero de Tejeda 2007).

Reclaimed wastewater intended for industrial use (Figure 2, A2) has been heavily marketed under the name NEWater in Singapore, where it is supplied directly to the industry in a separate distribution system. It has been a target to supply $20 \%$ of Singapore's water needs from recycled water (Public Utilities Board of Singapore 2007). The high quality water, essentially free of minerals, has proven so well accepted in Singapore's industry that newer projections estimate that NEWater will provide $30 \%$ of Singapore's water needs by 2010 (Seah, pers.comm., ${ }^{1}$ 2008).

\subsubsection{Indirect planned potable reclamation}

Indirect reclamation recirculates wastewater to drinking water via natural systems ( Figure 2, B1\&2). For example, in Singapore $2.5 \%$ of the drinking water supply is planned to be reclaimed wastewater by 2011 (Public Utilities Board of Singapore 2007; Tortajada 2006). A fraction of the water produced at the NEWater plants is already

\footnotetext{
${ }^{1}$ H. Seah, Personal communication 2008, Director, Technology \& Water Quality Office, Public Utilities Board, Singapore.
} 
blended with stored rainwater in existing drinking water reservoirs, and it constitutes around $1 \%$ of the current drinking water supply in Singapore. In Orange County, California, reclaimed municipal wastewater is pumped back to replace $30 \%$ of the water withdrawn from the aquifer. In Wulpen, Belgium, $70 \%$ of the water withdrawn from the aquifers is replaced with reclaimed wastewater. In these cases the artificial recharge of groundwater leads to substitution of 15 and $40 \%$ of total water demand, respectively ( Figure 1). These reclamation systems use several barriers to prevent pollutants from entering the drinking water supply. This is exemplified by the water reclamation system in Singapore (

Figure 3). In addition to conventional wastewater treatment the reclamation system use micro- or ultrafiltration combined with reverse osmosis and UV disinfection before mixing with the natural resource.

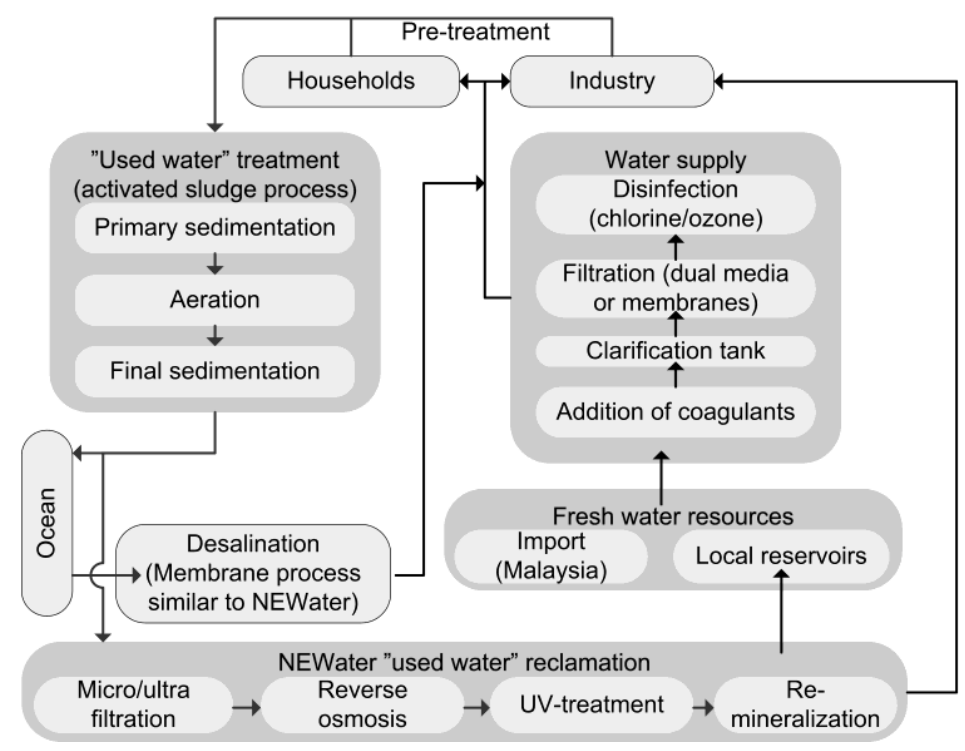

Figure 3. Singapore's water management and main treatment processes.

\subsubsection{Indirect un-planned potable reclamation}

Indirect potable reclamation occurs in an unplanned manner, where supply is based on 
water discharged by upstream users ( Figure 2, B3). For example, Berlin, Germany, has a water supply system entirely based on local groundwater abstraction. However $70 \%$ of groundwater withdrawal is recharged to the aquifer via artificial recharge through the river banks and the volume of treated wastewater returned to local surface water is more than the volume recharging aquifers via bank infiltration (Massmann et al. 2004). The influent to one local water works has been estimated to contain up to $28 \%$ wastewater (Ziegler 2001). Thus, although Berlin is not declared a reclamation system, it is so in practice and Berlin's water supply has a self-sufficiency ratio of $70 \%$. The ratio is high because groundwater abstraction is replaced by river water, which in turn is sourced from treated wastewater.

\subsubsection{Direct potable reclamation}

Currently, Windhoek, Namibia, remains the only large scale example of direct potable wastewater reclamation ( Figure 2, C). In Windhoek, the wastewater from households is kept separate from the industrial wastewater, treated through a series of processes, including flocculation, sandfiltration, ozonation, activated carbon filter, and ultrafiltration, before re-entering the city's water supply (du Pisani 2006). The system has the capacity to replace $35 \%$ of the water supply (Rygaard et al. 2009). Current selfsufficiency ratio is around $30 \%$ ( Figure 1).

\subsubsection{Desalination}

Membrane technologies are currently developing very rapidly with the number of membrane based treatment plants increasing and treatment costs decreasing. In addition to facilitate advanced treatment of wastewater for reclamation, the technology is also increasingly used for desalination of saline waters (Service 2006). Desalination has been used for decades in the arid Middle East, where desalination capacity now exceeds 16 
million $\mathrm{m}^{3} / \mathrm{d}$ (4 times the water supply of New York City, United States). The currently largest desalination plants in the world are based on thermal desalination of seawater and are also found in the Middle East, where single plant capacities exceed 800000 $\mathrm{m}^{3} / \mathrm{d}$ (Pacific Institute 2008). The world's largest reverse osmosis desalination plant is situated in Israel (>270 $000 \mathrm{~m}^{3} / \mathrm{d}$ ) (Tal 2006). In the countries of the Gulf Cooperation Council, 2/3 of domestic water is supplied from desalination (Dawoud 2005).

The booming growth in desalination capacity strongly correlates with a continuing drop in the unit production price. In the 1980 s around 8 million $\mathrm{m}^{3}$ desalinated water was produced globally per day, at costs of 1-3 dollars per $\mathrm{m}^{3}$. In 200554 million $\mathrm{m}^{3} / \mathrm{d}$ desalinated seawater was produced at a cost of as little as $0.5 \mathrm{US} \$ / \mathrm{m}^{3}$. The lowest costs are currently attained by state-of-the-art reverse osmosis plants (Reddy \& Ghaffour 2007). However, not all recent desalination projects achieve such low costs. For example, the newly opened Perth Desalination Plant has a production price of $1 \mathrm{US} \$ / \mathrm{m}^{3}$ (2006) (Crisp, pers.comm., 2006). Researchers are working to improve desalination performance and a vast range of technologies are being investigated on lab and pilot scale. These include improved membrane materials preventing fouling, while enhancing water flux and salt rejection, with the goal of lowering pressure needs and hence energy requirements. For cities with excess and waste heat sources, alternative technologies like forward osmosis and membrane distillation may be of interest if they become commercially attractive (Service 2006). The Perth Desalination Plant supplies $17 \%$ of the city's water demand. In Singapore, $140,000 \mathrm{~m}^{3} / \mathrm{d}$ corresponding to $10 \%$ of the total water demand will be provided by desalination by 2011 (Foo et al. 2007)( Figure 1).

\subsubsection{Rainwater collection}

Rainwater collection is another important contributor to urban water self-sufficiency. 
For example, Singapore plans by the end of 2007 to collect stormwater from $2 / 3$ of the island's area, store it in reservoirs like the new Marina Barrage, and membrane filter it before sending it to drinking water supply (Public Utilities Board of Singapore 2007). Decentralized rainwater collection for non-potable use is a simple technology frequently used to increase the self-sufficiency of urban areas. In London's Millennium Dome "Watercycle" experiment, water was collected from a roof area of $100000 \mathrm{~m}^{2}$, receiving $726 \mathrm{~mm}$ or $72,600 \mathrm{~m}^{3}$ during a one year study (Hills et al. 2002; Met office 2007). With a treatment capacity limited to $100 \mathrm{~m}^{3} / \mathrm{d}$ and storage limited to $300 \mathrm{~m}^{3}$ (to be shared with greywater reclamation from washbasins) it was possible to collect $18 \%$ of the received rainfall; a volume corresponding to $10 \%$ of the total water consumption in the building that year (Hills et al. 2001; Hills et al. 2002).

Our analysis reveals that many cities are now legislating collection of rainwater from roof tops with requirements depending on construction date, type and size of buildings, e.g. Stenløse, Denmark (Stenløse Kommune 2005). In the Southeast Queensland, Australia, the state development code directly refers to rainwater tanks and recycled water as recommended means to comply with strict water saving targets for new home owners (Queensland Government 2008). In these places, rooftop collected rainwater is used for toilet flushing, washing of clothes and garden irrigation. These cases confirm earlier studies which show that rainwater collection typically can substitute $25 \%$ of the household water consumption with the major limitation being the tank size (Mikkelsen et al. 1999).

Rooftop rainwater collection is an acknowledged and in several cases proven and effective way to replace drinking water consumption in households. 


\section{Challenges of self-sufficiency}

The main challenges of increased water self-sufficiency the water managers meet are:

- Controlling energy demands

- Controlling environmental impacts

- Ensuring high quality water and avoiding negative impacts on human health.

- Ensuring public trust in the water supply

- Ensuring cost effectiveness

\subsection{High energy demands}

Energy consumption has become increasingly relevant because it is linked to the climate change (Meehl et al. 2007). Environmental life cycle studies show that electricity consumption in the operation phase is generally the most important factor affecting environmental performance indicators in water treatment systems (Vince et al. 2008). Therefore, energy consumption is a good indicator of the environmental burden of the use of different water treatment techniques. In the following sections we discuss the energy demands revealed by our analysis and options for making those demands green house gas neutral so that they have no impact on our climate.

\subsubsection{Energy demand}

Alternatives involving advanced treatment processes are more energy intensive when compared to conventional treatment ( Figure 4), both in decentralized on-site applications and in centralized large scale systems. Small scale on-site reclamation systems based on membrane bioreactors are quite energy demanding $\left(2-8 \mathrm{kWh} / \mathrm{m}^{3}\right)$, 
depending on efficiency of scale. High energy requirements are also of concern for larger centralized systems and e.g. potable wastewater reclamation and desalination typically involve membrane technologies, which require high pressures (typically 5-80 bars) to force water through the membranes (Dreizin 2006; European Commission 2006).
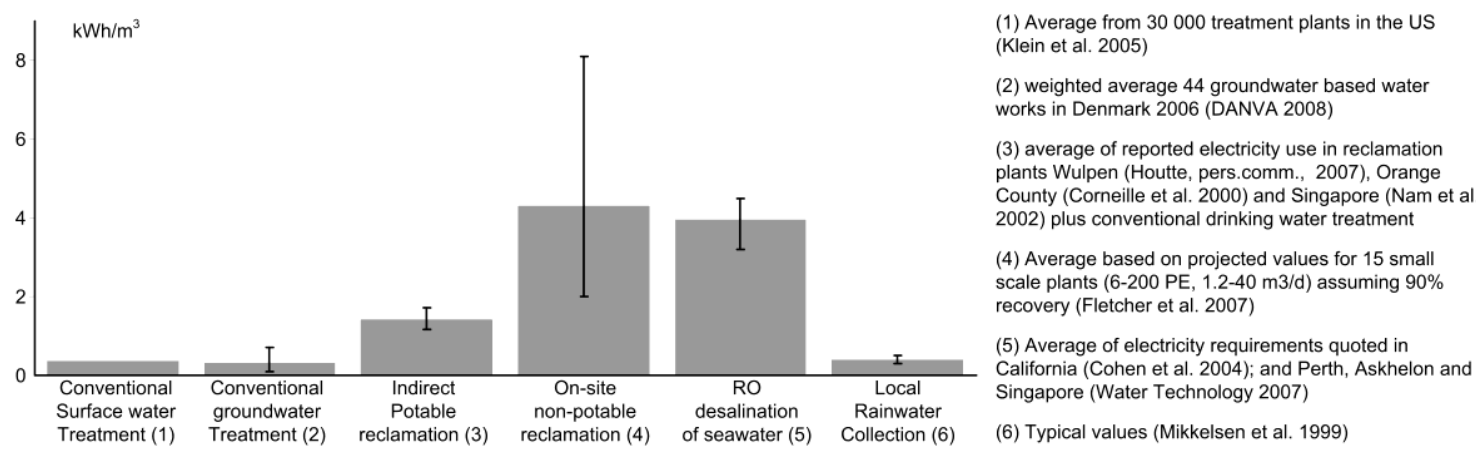
2002) plus conventional drinking water treatment

(4) Average based on projected values for 15 small scale plants $(6-200 \mathrm{PE}, 1.2-40 \mathrm{~m} 3 / \mathrm{d})$ assuming $90 \%$ recovery (Fletcher et al. 2007)

(5) Average of electricity requirements quoted in California (Cohen et al. 2004); and Perth, Askhelon and Singapore (Water Technology 2007)

Treatment (1) Treatment (2) reclamation (3) reclamation (4) of seawater (5) Collection (6) $\quad$ (6) Typical values (Mikkelsen et al. 1999)

Figure 4. Electricity demand per unit water produced before distribution with minimum and maximum values indicated.

State of the art seawater reverse osmosis treatment requires as little as $1.6 \mathrm{kWh}$ per $\mathrm{m}^{3}$ product water (excluding pretreatment) if operational conditions are optimal (Dundorf et al. 2007). In addition, the energy consumption by pre-treatment, aeration and disinfection steps must be considered. Newer seawater reverse osmosis plants typically require around $4 \mathrm{kWh} / \mathrm{m}^{3}$ including pretreatment ( Figure 4). Reducing seawater desalination energy requirement by more than $15 \%$ will require a breakthrough in alternative technologies (National Research Council 2008). Despite the high energy demand of seawater desalination, a recent review concluded that the energy requirements for desalination are less than commonly thought. In Israel, the energy used for drinking water treatment constitutes $3.2 \%$ of the total household energy consumption, if all water was produced as desalinated seawater (Semiat 2008). Although the marginal change in society's energy consumption is relatively small when 
desalination is employed, Figure $\mathbf{4}$ shows that there is a significant difference in the energy requirements of the water resource alternatives.

Cities in the vicinity of brackish water resources, such as the Baltic Sea, coastal groundwater or estuaries can benefit from significantly lower desalination energy consumptions. Using feed water with salinity of $15000 \mathrm{mg} / \mathrm{l}$ instead of $36000 \mathrm{mg} / \mathrm{l}$ requires less energy than treating ocean water, and the overall environmental life-cycle impact is reduced by almost 50\% (Munoz \& Fernandez-Alba 2008). Other environmental life-cycle assessments show that reclamation of wastewater is preferable to seawater desalination, because of the lower salinity of wastewater compared to seawater (Lundie et al. 2004; Raluy et al. 2005; Stokes \& Horvath 2006).

Household rainwater collection is energy efficient. In local rainwater collection systems where simple gravity driven screen filtering is used and a pump distributes the water to the household, the energy cost is $0.3-0.5 \mathrm{kWh} / \mathrm{m}^{3}$ (Mikkelsen et al. 1999). Rainwater collection can provide a low energy alternative to both reclamation and desalination because the electricity consumption is well below $1 \mathrm{kWh} / \mathrm{m}^{3}$ and is similar to conventional treatment of local groundwater and surface water resources.

\subsubsection{CO2-neutral water treatment}

Intensive water treatment and high energy demands can be decoupled from potential climate change impacts by use of emerging greenhouse-gas-neutral energy generation. In Perth, a desalination plant is powered by electricity bought from a wind farm. The wind farm has been constructed to offset the increased energy requirements of the water production (Water Corporation 2007).

In general, however, the construction of a wind farm under same budget as the 
desalination plant does not ensure $\mathrm{CO}_{2}$-neutral desalination. For example, current windpower technology has a capacity limit, due to its intermittency. Integration of windpower requires a stable and flexible base supply from other electricity sources connected to the grid. This can increase costs and decrease efficiency of the energy system (Benitez et al. 2008). If a governmental decision allocates a part of the windpower capacity to off-set a new demand, like desalination, it may restrict other electricity users from doing the same at reasonable costs. In such cases society misses an opportunity of reducing its dependency on other energy sources e.g. fossil fuels. Only a comprehensive life cycle assessment that acknowledges market effects can reveal positive or negative feedback mechanisms in the total environmental loading (Ekvall \& Weidema 2004). The response of energy markets to the increased demand posed by energy intensive water supply systems remains to be investigated.

In this paper energy evaluations have only included energy in the treatment and local distribution of the water. In case of water imports over long transport distances, low treatment energy demands may be off-set by large transport demands. Examples are found in both Spain and California, and show that planned desalination or wastewater reclamation schemes are expected to be more energy efficient than long transports of surface water (Raluy et al. 2005; Stokes \& Horvath 2006).

Small-scale systems have successfully decoupled desalination from the power grid, and work in isolated systems powered by renewable sources. Examples are wind turbines or photovoltaic solar panels coupled with reverse osmosis systems producing up to 50 $\mathrm{m}^{3} / \mathrm{d}$, but the actual implementation of these mature technologies remains low (Mathioulakis et al. 2007). Increasing energy costs and political pressure to be independent of fossil fuels could drive the development of these technologies to the 
larger sector. A climate and fossil fuel independent and in practice infinite fresh water supply is a very attractive option for most coastal cities, and coupling of membrane technology to renewable energy would be a further push for inland reclamation schemes.

\subsection{Environmental impact of feed water intakes and concentrate disposal}

Life cycle-assessment studies of water supply technologies do not currently include environmental impacts of water abstraction and disposal of concentrate from membrane processes. For example, seawater desalination draws water from a huge resource with environmental impacts very different from inland freshwater abstraction. Feed water intakes may include impacts on fish populations and invertebrates, and loss of biological productivity in general.

Depending on the recovery rate of the membrane processes, a concentrate stream containing 2-15 times the feed water concentrations is discharged to the recipients. The concentrate may also contain chemicals used in the pre-treatment, such as biocides, detergents and anti-scalants (Cooley et al. 2006). Chemicals are typically discharged in levels that are considered non-toxic to aquatic ecosystems at the individual level, but possible nutritional effects and combined effects remain to be investigated (National Research Council 2008).

Concentrate at the outlet can also alter flow and salinity levels in the local marine environment, as shown in the field investigations of Perth Desalination Plant, where a dense plume formed in the vicinity of the diffuser system is permanently present in calm wind conditions (Okely et al. 2007). One option (not often mentioned in the literature), is to blend the concentrate with existing wastewater discharges, and thereby obtain a 
combined dilution effect.

\subsection{Multiple barriers against micropollutants}

Cholera outbreaks and other waterborne diseases have taught us the inevitable importance of effective barriers between water resources polluted with pathogens and drinking water (Dawson \& Sartory 2000; Osborne 2008). Today's wastewater streams contain a wide range of chemical pollutants that pose risks to ecosystems and drinking water systems (Schwarzenbach et al. 2006). Controlling the release of pollutants to the waste streams is much more efficient than performing a difficult removal at treatment plants (Levine \& Asano 2004; Schwarzenbach et al. 2006).

However, trace levels of compounds like pharmaceuticals are already widely present in available wastewater streams and fresh water resources (Halling-Sorensen et al. 1998; Kolpin et al. 2002). It is important to acknowledge that even reverse osmosis treatment does not provide a complete barrier against pharmaceutical active and endocrine disrupting compounds. Rejection of these compounds by RO-membranes is effective but range from 40-100\% for selected compounds and membranes (Kimura et al. 2004; Radjenovic et al. 2008). The mechanisms controlling rejection are complex and depend both compound and membranes specific properties (Bellona et al. 2004). Therefore, several barriers are often installed to prevent unwanted pollutants from entering the water supply. For example, Singapore's water loop and its "double membrane" set-up, consists of several treatment steps including microfiltration, reverse osmosis, UVoxidation, and dilution in surface reservoirs. This multi-barrier approach effectively reduces the risk of transmitting micropollutants from wastewater to the potable water supply (Public Utilities Board of Singapore 2007; Tortajada 2006). 
Even in such advanced water reclamation projects, some trace pollutants (e.g. formaldehyde, EDTA, 1,4-DCB) are known to pass membranes and oxidation processes, and are detected in the reclaimed water, e.g. in both the NEWater plants in Singapore and the pilot groundwater replenishment system in Orange County, CA (Burris \& Herndon 2000; Nam et al. 2002).

It is therefore no surprise that in simpler reclamation systems like Berlin's, pharmaceutical compounds occur (ng/l-level) in tap water. The compounds do not degrade in the months to years travel time from the river bank to abstraction wells (Massmann et al. 2008). Berlin relies on simple sand filtration and aeration, but the artificial recharge and underground filtration still provide an efficient but incomplete barrier for e.g. pharmaceuticals and their metabolites (Heberer 2002; Zuehlke et al. 2007).

In Berlin, Orange County and Singapore, risk assessments concluded that the $\mu \mathrm{g} / \mathrm{l}$ and ng/l-level of the compounds pose no risk for human health. However, such risk assessments are still based on the effects of individual compounds and recently there was called for increased focus on the cumulative risk of simultaneous exposure to environmental stressors (Sexton \& Hattis 2007). Combinations of toxicants have been shown to increase damages in mammals. For example, co-exposure of neonatal mice to polybrominated diphenyl ethers (PBDEs) and polychlorinated biphenyls (PCBs) can exacerbate toxic effects, relative to exposure to the individual compound (Eriksson et al. 2006). Both types of contaminants are present in wastewater and known to reach recipients even after wastewater treatment and infiltration processes (Vogelsang et al. 2006; Zhang et al. 2008). These results suggest that compounds present in water reclamation systems may interact and imply a risk not present from the individual 
compounds.

\subsection{Public acceptance and trust}

Interpreting the risk posed by mixtures of low level contamination is challenging for the scientific community (Sexton \& Hattis 2007), and therefore even more so for the public.

\subsubsection{Will people drink reclaimed water?}

Recent improvements in analytical methods, increased focus on micropollutants, and wide-spread pollution of our waterways, have made it necessary to accept drinking water that is known to be contaminated by unwanted pollutants, although at very low concentrations. This conflict between the ability to analyze very low contaminant concentrations and a wish to drink clean water can be difficult for the public and decision makers to accept. Potable reclamation schemes are especially challenging since the short circuiting of the water loop is particularly evident for the public. Analyses of public perception have confirmed that people are more positive towards reclamation when they are not in direct contact with the water. Thus, reclaimed water is preferably used for toilet flushing rather than cooking at home (Po et al. 2005).

Studies show that public perception of water quality is mainly related to trust in relevant agencies and personal perceptions of control rather than technical parameters of water quality (Fawell \& Miller 1992; Po et al. 2005; Syme \& Williams 1993). It has further been suggested that the history of the reclaimed water is of less importance than the process in which a decision to recycle the water is made (Russell \& Lux 2009). To avoid misunderstandings and build trust, it seems crucial that new initiatives are preceded by public engagement and interaction between decision makers and the public.

One good example is the 2006 ballot on wastewater reclamation in Toowoomba, 
Australia. There the public turned down a governmental proposition to add reclaimed wastewater to the city's drinking water reservoirs. Even though wastewater reclamation was considered to be a technical and economic optimal solution, $62 \%$ of the voters were against the project and the government was forced to look for other solutions. Arguments against the reclamation scheme centered on the perceived credibility of the government's decisions, and in some instances were even wrong, as seen from the quotes from those opposed to water reclamation: "The Water Futures project was developed in secrecy. Trust is now missing" and "Nowhere else in the world deliberately drinks water reclaimed from sewage to the degree [25\%] proposed by Toowoomba" [our comment in brackets] (Toowoomba City Council 2006). Our review reveals that people are willing to drink reclaimed water at similar self-sufficiency ratios, i.e. Windhoek (22\%), Wulpen (41\%) and Orange County (15\%). So in some instances people are willing to drink reclaimed water.

\subsubsection{Convincing people}

The sensitivity of the public to new technologies may have undesirable consequences. There is a possibility that people will turn away from tap water to bottled water, and this may have undesired implications, like increased costs and environmental burdens due to plastic consumption. Producing disposable plastic bottles is very energy intensive, typically using 50-70 kWh electricity per 10001 product volume depending on size of the bottle (Ekvall et al. 1998). Plastic bottle consumption and the relatively high sales price of bottled water also add to the negative impact of a shift from tap water to bottled water.

Public acceptance during the implementation of self-sufficient water is critical for success. In Singapore a combination of expert opinion published as an "expert panel 
review", and an extensive PR-strategy including a NEWater exhibition centre aimed at the general public, was used to maintain and ensure trust in the public water supply (Nam et al. 2002; Public Utilities Board of Singapore 2007).

The important lesson must be that even if scientifically sound assessments conclude that wastewater reclamation is the best available option, actual planning and public communication can be the decisive factors for implementation. It is essential that the impact of human exposure to micropollutants is correctly analyzed and explained to the public. Unless a strict precautionary approach (Kriebel et al. 2001) is chosen, the additional risks of using alternative water resources must be carefully evaluated and periodically reassessed as new evidence is presented.

\subsection{Costs}

Comparing the costs of different techniques is challenging as they will depend a range of factors that may vary significantly with location and be implementation specific. Keeping in mind this caveat, a comparison of costs shows that they vary greatly within and between solutions (Table 5).

Table 5. Expected costs of technologies reported for Australia (Pickering et al. 2007) except * generic estimates for an MBR-system (Fletcher et al. 2007).

\begin{tabular}{lll}
\hline Production price $\left(\mathbf{U S} \$ \mathbf{m}^{\mathbf{3}}\right)$ & Min & Max \\
\hline Conventional surface water treatment & 0.1 & 2.2 \\
Conventional groundwater treatment & 0.2 & 1.2 \\
Indirect potable reuse & 1.3 & 2.0 \\
On-site non-potable reuse* & 1.3 & 4.2 \\
RO seawater desalination & 0.9 & 2.2 \\
Local rainwater collection & 0.1 & 1.1 \\
\hline
\end{tabular}


Important factors include size and energy costs. For example, the cost of on-site wastewater reclamation is directly related to the size of the plant. A small membrane bio-reactor plant installed to serve a single household (producing $400 \mathrm{~m}^{3} / \mathrm{y}$ ) is predicted to have a total cost in the range of 3.8-4.2 US\$ $\$ \mathrm{~m}^{3}$. Membrane bioreactor plants, up-scaled to serve a block of houses and producing $\sim 13000 \mathrm{~m}^{3} / \mathrm{y}$ is expected to cost 1.5-2.3 US\$ $\$ \mathrm{~m}^{3}$ (Based on Fletcher et al. 2007). The variance is due to the choice of membrane bioreactor design. It is not surprising that costs are related to treatment intensity. It is seen that the lower bounds of estimated cost are significantly higher for indirect potable reclamation, on-site treatment and desalination than for more conventional sources and simple concepts such as surface water abstraction and rainwater collection (Table 5).

A simple comparison of costs can often be misleading, and more holistic economic assessments are needed, including costs and benefits of externalities. Supplying reclaimed water or rainwater in separate distribution systems as a secondary water supply for toilet flushing, irrigation and clothes washing may be expensive in the construction phase. However, other benefits emerge since a compromise is not needed between low capacity/high quality demand for drinking water and the high capacity/low quality demand for e.g. fire hydrants and lawn watering. In the same way, large scale rainwater collection and local wastewater reclamation has to be evaluated in an integrated manner where lower demand for sewage capacity is included in the assessment. Holistic feasibility studies might prove local wastewater reclamation and rainwater collection to be feasible in more cases. 


\subsection{No single concept is a panacea to urban water stress}

There is unfortunately no simple panacea to urban water stress. Each type of resource has its own strengths and weaknesses ( Figure 5). Wastewater reclamation and desalination are effective ways of increasing water self-sufficiency, while reducing the impact of climate variations, because such climate independent water resources can provide a steady freshwater yield in dry periods. However, wastewater reclamation and desalination becomes less optimal when considering public acceptance and treatment intensity, which reflects energy consumption and costs.
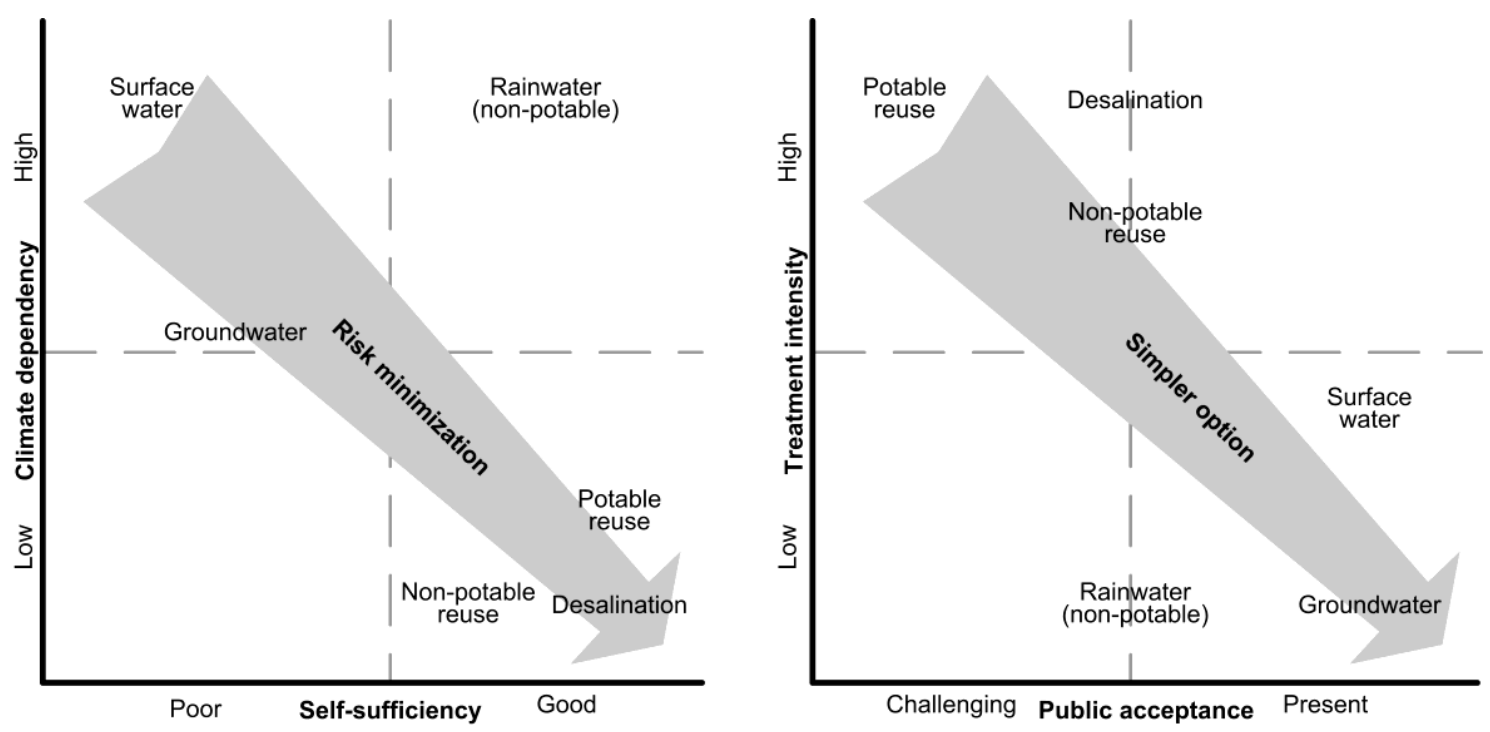

Figure 5. Properties of resources for urban water supply.

Due to losses or intermittency, wastewater reclamation and rainwater collection cannot separately ensure complete urban self-sufficiency, and desalination is often the more expensive option. However, a diversified water system is more flexible and secure against policy changes and natural variability and the panacea may actually be diversification.

There are only few reports of such truly diversified and integrated urban water management projects, with Singapore as the best example. Technical solutions and public relations are 
Figure 3 and section 4.4.2). Full integration of water demand management, wastewater reclamation, desalination and rainwater collection can provide self-sufficiencies as high as $80 \%$, as seen in Pimpama-Coomera, Australia ( Figure 1).

\section{Conclusion}

Based on a review of 113 cases of increased water self-sufficiency, and an in-depth analysis of 15 cases, it is concluded that:

- Although increased water self-sufficiency is a predictable response to urbanization and increasing water stress, we found it surprising to find that several cities already taking advantage of low grade water resources within the city boundaries. Many cities reclaim wastewater and collect rainwater, and desalination is becoming increasingly common worldwide.

- Self-sufficient water supplies are driven by direct (physical) and indirect (political) water deficits, concerns of water quality, and constrained water infrastructure. The inter disciplinary nature of the drivers emphasizes that water management is not just an engineering challenge.

- Calculating the degree of water self-sufficiency allows direct comparison of cases. The self-sufficiency ratios between $15-80 \%$ are observed: from small scale implementations like local rainwater collection providing $25 \%$ of the household consumption in Stenløse, Denmark, to citywide water management strategies with desalination and wastewater reclamation plants producing more than $100000 \mathrm{~m}^{3}$ of water per day, as seen in Singapore. 
- The steady demand for water in cities results in a stable supply of wastewater that can be used for both non-potable and potable purposes. Examples of potable reclamation of wastewater include desert and remote areas like Windhoek, Namibia, and densely populated areas like Singapore and Wulpen, Belgium. In some places water has been reclaimed for potable consumption for decades, e.g. Orange County, California.

The move to self-sufficiency concepts has some major implications:

- Energy consumption varies by an order of magnitude for different technologies and is directly linked to production volume and is therefore a critical parameter in water systems design. From societal perspective the energy consumption of water production can be of less importance relative to other energy uses. On the other hand, it is important that the current focus on energy issues does not overshadow the deficient understanding of the effects on the marine environment from feed water intake and concentrate disposal.

- Reclamation of wastewater as source for drinking water introduces a special challenge due to a lack of scientific understanding of human exposure to micropollutants and the possible risk such a water technology can add to that exposure. A better understanding of long term effects from the combined exposure to micro and nanogram levels of pollutants is necessary before potable reclamation of wastewater can be judged to be absolutely without risk for the population.

- Two-way communication is the crucial issue when convincing the public that new technologies are safe. In some places, people have been convinced to adopt 
wastewater reclamation schemes for water supply, while in others proposals for reclamation schemes have been rejected by the public.

The desire for self-sufficiency is a major trend and driver for new technologies and concepts in modern water supplies. Technologies like wastewater reclamation, desalination and rainwater collection are attractive because of their reliability and stability. They will become increasingly common as water utilities seek more secure solutions by diversifying their approaches to water supply.

\section{Acknowledgement}

The work was partly sponsored by Copenhagen Energy 


\section{References}

Bellona, C., Drewes, J. E., Xu, P., \& Amy, G. 2004, "Factors affecting the rejection of organic solutes during NF/RO treatment - a literature review", Water Research, vol. 38, no. 12 , pp. $2795-2809$.

Benitez, L. E., Benitez, P. C., \& van Kooten, G. C. 2008, "The economics of wind power with energy storage", Energy Economics, vol. 30, no. 4, pp. 1973-1989.

Burris, D. L. \& Herndon, R. L. 2000, Title 22 engineering report for the groundwater replenishment system, Orange County Water District and Orange County Sanitation District, California.

Chu, J. Y., Chen, J. N., Wang, C., \& Fu, P. 2004, "Wastewater reuse potential analysis: implications for China's water resources management", Water Research, vol. 38, no. 11, pp. 2746-2756.

Cohen, R., Nelson, B., \& Wolff, G. 2004, Energy down the drain: The hidden costs of California's water supply, Natural Resources Defence Council \& Pacific Institute, Oakland, California.

Cooley, H., Gleick, P. H., \& Wolff, G. 2006, Desalination, with a grain of salt, Pacific Institute for Studies in Development, Environment, and Security.

Corneille, R., Chalmers, R. B., Cutler, D., Cruz, C., Dy, D., \& . 2000, Groundwater Replenishment System. Project development phase - development information memorandum \#31, Camp Dresser \& McKee, California.

DANVA. DANVA Benchmarking og statistik (Danish Water and Wastewater 
Association - Benchmarking and statistics). www.bessy.dk, Accessed 7 August 2008.

Dawoud, M. A. 2005, "The role of desalination in augmentation of water supply in GCC countries", Desalination, vol. 186, no. 1-3, pp. 187-198.

Dawson, D. J. \& Sartory, D. P. 2000, "Microbiological safety of water", British Medical Bulletin, vol. 56, no. 1, pp. 74-83.

Dreizin, Y. 2006, "Ashkelon seawater desalination project - off-taker's self costs, supplied water costs, total costs and benefits", Desalination, vol. 190, no. 1-3, pp. 104116.

du Pisani, P. L. 2006, "Direct reclamation of potable water at Windhoek's Goreangab reclamation plant", Desalination, vol. 188, no. 1-3, pp. 79-88.

Dundorf, S., MacHarg, J., \& Seacord, T. F. "Optimizing Lower Energy Seawater Desalination, The Affordable Desalination Collaboration", International Desalination Association World Congress, Grand Canarias.

Ekvall, T., Person, L., Ryberg, A., Widheden, J., Frees, N., Nielsen, P. H., Pedersen, B. W., \& Wesnæs, M. 1998, Life cycle assessment of packaging systems for beer and soft drinks. Main report, Danish Environmental Protection Agency, Copenhagen, Denmark.

Ekvall, T. \& Weidema, B. P. 2004, "System boundaries and input data in consequential life cycle inventory analysis", International Journal of Life Cycle Assessment, vol. 9, no. 3 , pp. $161-171$.

Eriksson, P., Fischer, C., \& Fredriksson, A. 2006, "Polybrominated diphenyl ethers, a group of brominated flame retardants, can interact with polychlorinated biphenyls in 
enhancing developmental neurobehavioral defects", Toxicological Sciences, vol. 94, no. 2, pp. 302-309.

European Commission 2006, Water reuse system management manual - AQUAREC Office for Official Publications of the European Communities, Luxembourg.

Fatta, D., Anayiotou, S., rslan-Alaton, I., Ayoub, G. M., Rusan, M. M., Hameed, K. M., \& Loizidou, M. 2006, "The water profile and the policies that need to be developed for the promotion of wastewater reuse in the Mediterranean countries: the case of Cyprus, Jordan and Lebanon", International Journal of Environment and Pollution, vol. 28, no. 1-2, pp. 45-56.

Fawell, J. K. \& Miller, D. G. 1992, "Drinking-Water Quality and the Consumer", Journal of the Institution of Water and Environmental Management, vol. 6, no. 6, pp. 726-732.

Fletcher, H., Mackley, T., \& Judd, S. 2007, "The cost of a package plant membrane bioreactor", Water Research, vol. 41, no. 12, pp. 2627-2635.

Foo, H. K., Yong, W. W. L., \& Ratnayaka, D. D. 2007, "The Singapore Solutions", Civil Engineering, vol. 77, no. 1, pp. 62-69.

Halling-Sorensen, B., Nielsen, S. N., Lanzky, P. F., Ingerslev, F., Lutzhoft, H. C. H., \& Jorgensen, S. E. 1998, "Occurrence, fate and effects of pharmaceutical substances in the environment - A review", Chemosphere, vol. 36, no. 2, pp. 357-394.

Hallström, J. 2003, Constructing a Pipe-Bound City: A History of Water Supply, Sewerage, and Excreta Removal in Norrköping and Linköping, Sweden, 1860-1910, 
Doctoral thesis, The Tema Institute, Department of Water and Environmental Studies, Linköping University, Sweden.

Han, M. \& Kim, S. 2007, "Local Water Independency Ratio (LWIR) as an index to define the sustainability of major cities in Asia", 4th IWA Specialist Conference on Efficient Use and Management of urban Water Supply, Jeju Korea.

Heberer, T. 2002, "Tracking persistent pharmaceutical residues from municipal sewage to drinking water", Journal of Hydrology, vol. 266, no. 3-4, pp. 175-189.

Hills, S., Birks, R., \& McKenzie, B. 2002, "The Millennium Dome "Watercycle" experiment: to evaluate water efficiency and customer perception at a recycling scheme for 6 million visitors", Water Science and Technology, vol. 46, no. 6-7, pp. 233-240.

Hills, S., Smith, A., Hardy, P., \& Birks, R. 2001, "Water recycling at the Millennium Dome", Water Science and Technology, vol. 43, no. 10, pp. 287-294.

Hochstrat, R., Wintgens, T., Melin, T., \& Jeffrey, P. 2006, "Assessing the European wastewater reclamation and reuse potential - a scenario analysis", Desalination, vol. 188, no. 1-3, pp. 1-8.

Kimura, K., Toshima, S., Amy, G., \& Watanabe, Y. 2004, "Rejection of neutral endocrine disrupting compounds (EDCs) and pharmaceutical active compounds (PhACs) by RO membranes", Journal of Membrane Science, vol. 245, no. 1-2, pp. 7178.

Klein, G., Krebs, M., Hall, V., O'brien, T., \& Blevins, B. B. 2005, California's water energy relationship, California Energy Commission. 
Kolpin, D. W., Furlong, E. T., Meyer, M. T., Thurman, E. M., Zaugg, S. D., Barber, L. B., \& Buxton, H. T. 2002, "Pharmaceuticals, hormones, and other organic wastewater contaminants in US streams, 1999-2000: A national reconnaissance", Environmental Science \& Technology, vol. 36, no. 6, pp. 1202-1211.

Kriebel, D., Tickner, J., Epstein, P., Lemons, J., Levins, R., Loechler, E. L., Quinn, M., Rudel, R., Schettler, T., \& Stoto, M. 2001, "The precautionary principle in environmental science", Environmental Health Perspectives, vol. 109, no. 9, pp. 871876.

Lallana, C. \& Marcuello, C. 2004, (WQ1) Water exploitation index, European Environmental Agency, Copenhagen, Denmark.

Landers, J. 2008, "Singapore Plans Two More Reuse Plants, Increasing Its Reliance On Reclaimed Water", Civil Engineering, vol. 78, no. 8, pp. 33-35.

Levine, A. D. \& Asano, T. 2004, "Recovering sustainable water from wastewater", Environmental Science \& Technology, vol. 38, no. 11, pp. 201A-208A.

Lundie, S., Peters, G. M., \& Beavis, P. C. 2004, "Life Cycle Assessment for sustainable metropolitan water systems planning", Environmental Science \& Technology, vol. 38, no. 13 , pp. $3465-3473$.

Malerba, F. 2002, "Sectoral systems of innovation and production", Research Policy, vol. 31, no. 2, pp. 247-264.

Martine, G. 2007, State of world population 2007, United Nations Population Fund, New York. 
Massmann, G., Knappe, A., Richter, D., \& Pekdeger, A. 2004, "Investigating the influence of treated sewage on groundwater and surface water using wastewater indicators in Berlin, Germany", Acta Hydrochimica et Hydrobiologica, vol. 32, no. 4-5, pp. 336-350.

Massmann, G., Sultenfuss, J., Dunnbier, U., Knappe, A., Taute, T., \& Pekdeger, A. 2008, "Investigation of groundwater a residence times during bank filtration in Berlin: multi-tracer approach", Hydrological Processes, vol. 22, no. 6, pp. 788-801.

Mathioulakis, E., Belessiotis, V., \& Delyannis, E. 2007, "Desalination by using alternative energy: Review and state-of-the-art", Desalination, vol. 203, no. 1-3, pp. 346-365.

Mays, L. W., Koutsoyiannis, D., \& Angelakis, A. N. 2007, "A brief history of urban water supply in antiquity", Water Science and Technology: Water Supply, vol. 7, no. 1, pp. 1-12.

Meehl, G. A., Stocker, T. F., Collins, W. D., Friedlingstein, P., Gaye, A. T., Gregory, J. M., Kitoh, A., Knutti, R., Murphy, J. M., Noda, A., Raper, S. C. B., Watterson, I. G., Weaver, A. J., \& Zhao, Z.-C. 2007, "Global climate projections," in Climate Change 2007: The Physical Science Basis. Contribution of Working Group I to the Fourth Assessment Report of the Intergovernmental Panel on Climate Change, S. Solomon et al., eds., Cambridge University Press, Cambridge UK \& New York NY USA.

Met office. http://www.metoffice.gov.uk. Accessed 27 July 2007.

Mikkelsen, P. S., Adeler, O. F., Albrechtsen, H. J., \& Henze, M. 1999, "Collected rainfall as a water source in Danish households - What is the potential and what are the 
costs?", Water Science and Technology, vol. 39, no. 5, pp. 49-56.

Mulder, K. 2006, Sustainable Development for Engineers Greenleaf Publishing Ltd., Sheffield, UK.

Munoz, I. \& Fernandez-Alba, A. R. 2008, "Reducing the environmental impacts of reverse osmosis desalination by using brackish groundwater resources", Water Research, vol. 42, no. 3, pp. 801-811.

Nam, O. C., Rose, J., Lauer, W., Jern, N. W., Kai, C. S., Tam, J. P., Singh, M., \& Kee, L. H. 2002, Singapore reclamation study: Expert panel review, Singapore.

National Research Council 2008, Desalination: A national perspective, The National Academies Press, Washington DC.

Ogoshi, M., Suzuki, Y., \& Asano, T. 2001, "Water reuse in Japan", Water Science and Technology, vol. 43, no. 10, pp. 17-23.

Okely, P., Antenucci, J. P., Imberger, J., \& Martin, C. L. "Field investigations into the impacts of the Perth Seawater Desalination Plant discharge on Cockburn Sound", Centre for Water Research, University of Western Australia, Nedlands, WA, Australia. Osborne, J. B. 2008, "Preparing for the pandemic: City boards of health and the arrival of cholera in Montreal, New York, and Philadelphia in 1832", Urban History ReviewRevue D Histoire Urbaine, vol. 36, no. 2, pp. 29-42.

Pacific Institute. Water data from The World's Water. http://www.worldwater.org/data.html . 2008.

Po, M., Nancarrow, B. E., Leviston, Z., Porter, N. B., Syme, G. J., \& Kaercher, J. D. 
2005, Predicting Community Behaviour in Relation to Wastewater Reuse. What Drives Decisions to Accept or Reject?, CSIRO Land and Water, Perth, Australia.

Public Utilities Board of Singapore. NEWater \& Marina Barrage, www.pub.gov.sg. Accessed 31 May 2007.

Queensland Government. Queensland Development Code 10 April 2008. MP4.2 Water savings targets, Department of Infrastructure and Planning, Brisbane, Australia.

Radjenovic, J., Petrovic, M., Ventura, F., \& Barcel, D. 2008, "Rejection of pharmaceuticals in nanofiltration and reverse osmosis membrane drinking water treatment", Water Research, vol. 42, no. 14, pp. 3601-3610.

Raluy, R. G., Serra, L., Uche, J., \& Valero, A. 2005, "Life cycle assessment of water production technologies - Part 2: Reverse osmosis desalination versus the Ebro River Water Transfer", International Journal of Life Cycle Assessment, vol. 10, no. 5, pp. 346354.

Reddy, K. V. \& Ghaffour, N. 2007, "Overview of the cost of desalinated water and costing methodologies", Desalination, vol. 205, no. 1-3, pp. 340-353.

Russell, S. \& Lux, C. 2009, "Getting over yuck: moving from psychological to cultural and sociotechnical analyses of responses to water recycling", Water Policy, vol. 11, no. 1, pp. 21-35.

Rygaard, M., Albrechtsen, H.-J., \& Binning, P. J. 2009, Alternative water management and self-sufficient water supplies IWA Publishing, London, UK.

Sala, L. \& Romero de Tejeda, S. "Use of reclaimed water in the recreation and 
restoration of aquatic ecosystems: practical experience in the Costa Brava region (Girona, Spain)", 6th Conference on Wastewater Reclamation and Reuse for Sustainability, Antwerp, Belgium.

Schwarzenbach, R. P., Escher, B. I., Fenner, K., Hofstetter, T. B., Johnson, C. A., von Gunten, U., \& Wehrli, B. 2006, "The challenge of micropollutants in aquatic systems", Science, vol. 313, no. 5790, pp. 1072-1077.

Semiat, R. 2008, "Energy Issues in Desalination Processes", Environmental Science \& Technology, vol. 42, no. 22, pp. 8193-8201.

Service, R. F. 2006, "Desalination freshens up", Science, vol. 313, no. 5790, pp. 10881090.

Sexton, K. \& Hattis, D. 2007, "Assessing cumulative health risks from exposure to environmental mixtures - Three fundamental questions", Environmental Health Perspectives, vol. 115, no. 5, pp. 825-832.

Stenløse Kommune. Lokalplan, Stenløse Syd etape 1 (District Plan, Stenløse Syd Stage 1). 3.1.1. 26-1-2005.

Stokes, J. \& Horvath, A. 2006, "Life cycle energy assessment of alternative water supply systems", International Journal of Life Cycle Assessment, vol. 11, no. 5, pp. 335343.

Syme, G. J. \& Williams, K. D. 1993, "The Psychology of Drinking-Water Quality - An Exploratory-Study", Water Resources Research, vol. 29, no. 12, pp. 4003-4010.

Tal, A. 2006, "Seeking sustainability: Israel's evolving water management strategy", 
Science, vol. 313, no. 5790, pp. 1081-1084.

The European Parliament and the Council of the European Union. EU Water Framework Directive. 2000/60/EC, .

Toowoomba City Council. Water futures Toowoomba 2006.

http://www.toowoombawater.com.au. Accessed 11 June 2007.

Tortajada, C. 2006, "Water management in Singapore", International Journal of Water Resources Development, vol. 22, no. 2, pp. 227-240.

van Roon, M. 2007, "Water localisation and reclamation: Steps towards low impact urban design and development", Journal of Environmental Management, vol. 83, no. 4, pp. 437-447.

Vince, F., Aoustin, E., Breant, P., \& Marechal, F. 2008, "LCA tool for the environmental evaluation of potable water production", Desalination, vol. 220, no. 1-3, pp. 37-56.

Vogelsang, C., Grung, M., Jantsch, T. G., Tollefsen, K. E., \& Liltved, H. 2006, "Occurrence and removal of selected organic micropollutants at mechanical, chemical and advanced wastewater treatment plants in Norway", Water Research, vol. 40, no. 19, pp. 3559-3570.

Ward, F. A., Booker, J. F., \& Michelsen, A. M. 2006, "Integrated Economic, Hydrologic, and Institutional Analysis of Policy Responses to Mitigate Drought Impacts in Rio Grande Basin", Journal of Water Resources Planning and Management, vol. 132 , no. 6 , pp. $488-502$. 
Water Corporation 2007, Annual report 2007, Perth, Australia.

Water Technology. Industry projects. http://www.water-technology.net/projects. 2007. Accessed 15 January 2007.

WaterHub. WaterHub. http://www.pub.gov.sg/waterhub. 2008. Accessed 9 December 2008

Yamagata, H., Ogoshi, M., Suzuki, Y., Ozaki, M., \& Asano, T. 2003, "On-site water recycling systems in Japan", Water Science and Technology: Water Supply, vol. 3, no. 3, pp. 149-154.

Zhang, J. M., Tomanek, M., Dong, H., Arnold, R. G., Ela, W. P., Quanrud, D. M., \& Saez, A. E. 2008, "Fate of polybrominated diphenyl ethers, nonylphenol, and estrogenic activity during managed infiltration of wastewater effluent", Journal of Environmental Engineering-Asce, vol. 134, no. 6, pp. 433-442.

Ziegler, D. H. 2001, Untersuchungen zur nachhaltigen Wirkung der Uferfiltration im Wasserkreislauf Berlins (Studies on the effect of sustained bank infiltration in the water cycle of Berlin, in German), PhD thesis, Technischen Universitet Berlin, Germany. Zuehlke, S., Duennbier, U., \& Heberer, T. 2007, "Investigation of the behavior and metabolism of pharmaceutical residues during purification of contaminated ground water used for drinking water supply", Chemosphere, vol. 69, no. 11, pp. 1673-1680. 